Journal of Educational Informatics (2016), 1, 1-25

\title{
Technology Use in Early Childhood Education: A Review of Literature
}

\author{
NANCY R. ZOMER AND ROBIN H. KAY \\ University of Ontario Institute of Technology \\ Canada \\ robin.kay@uoit.ca \\ ruth.zomer@uoit.ca
}

This paper provides a review of the literature from 2009 to 2014 on student use of technology in early childhood education. Previous efforts to synthesize the literature are somewhat dated, non-specific about age range, and focus almost exclusively on literacy. Thirty peer-reviewed articles from 11 countries, selected from a comprehensive search of the literature, were organized under five main categories: literacy, engagement, social interactions, mathematics, and miscellaneous topics. The overall effect size, based on only 12 studies and 33 measures was moderately high $(\mathrm{d}=0.71$, $\mathrm{SD}=0.60$ ). Considerable qualitative and quantitative evidence indicated that technology had a significant impact on literacy development. Fewer studies, mostly qualitative in design and small in sample size, reported that technology had a positive impact on engagement, social interactions, and mathematics skills. A handful of studies provided qualitative evidence that technology had a positive impact on sequencing, visual perception, creative thinking, and fine motor capability. Methodological concerns included limited sample sizes and descriptions, not documenting the consistency and accuracy data of collection tools, the extent of adult intervention, and the limited range of technology tools used. 


\section{INTRODUCTION}

For the purpose of this review, the term technology refers to digital technologies in the form of hardware (e.g., interactive whiteboards, tablets), stand-alone software (e.g., CDROMs, e-books), and online learning tools (e.g., Monster Exchange, ABRACADABRA). Historically, theorists and researchers have debated whether young children should use technology at school (Alper, 2011; Blackwell, 2013; Cordes \& Miller, 2000; Kirkorian, Wartella, \& Anderson, 2008; House, 2012; Lindahl \& Folkesson, 2012; Morgan, 2010, Parett, Quesenberry \& Blum 2010, Plowman \& McPake, 2013). One side argues that using technology is developmentally inappropriate because young children need to consolidate their knowledge using concrete materials (Cordes \& Miller, 2000; Healy, 2004; House, 2012; Plowman \& Stephen, 2003). In addition, too much screen time can overload a young child's senses (House, 2012) resulting in attention difficulties and poor concentration (Cordes \& Miller, 2000; House, 2012). Furthermore, overuse of technology could put young children at risk of developing muscular-skeletal injuries (Cordes \& Miller, 2000; Plowman \& Stephen, 2003) and visual difficulties (Cordes \& Miller, 2000). Other possible detrimental effects of technology use at a young age include impaired literacy skills, loss of imagination (Cordes \& Miller, 2000) and a lack of social skills, resulting in social isolation (Cordes \& Miller, 2000; Healy, 2004).

The other side of the debate argues that developmentally appropriate use of technology can enhance young children's learning (Blackwell, 2013; Blackwell, Lauricella, \& Wartella, 2014; Hillman \& Marshall, 2009; Lindahl \& Folkesson, 2010; Plowman \& Stephen, 2003; Vernadakis, Avgerinos, Tsitskari, \& Zachopoulou, 2005), particularly in the area of emergent literacy skills (Cassell, 2004; Parette, Quesenberry, \& Blum, 2010; Plowman, Stevenson, McPake, Stephen, \& Adey, 2011). Technology use for younger children has been associated with increased motivation (Lindahl \& Folkesson, 2010; Plowman \& Stephen, 2003; Vernadakis et al., 2005), student-centered learning practices (Blackwell, 2013), the development of social skills through collaboration (Alper, 2011; Cassell, 2004; Cicconi, 2014; Lieberman, 2009; Shifflet, Toledo, \& Mattoon, 2012), and supporting children with disabilities and special needs (Cordes \& Miller, 2000; Hutinger \& Johanson, 2000; Muligan, 2003).

More recently, the debate has shifted from whether technology should be used in early childhood settings, to how it should be used and whether it makes a difference in children's learning and development (Ko \& Chou, 2014; Parette et al., 2010; Rosen \& Jaruszewicz, 2009). The question for educators and policy-makers has become how to best integrate technology into pedagogical practice and curriculum design in early childhood settings (Plowman, McPake, \& Stephen, 2012). Several researchers have recommended that practitioners take a thoughtful approach to the use of technology by carefully considering the design of the technology to determine if it supports creativity, curiosity, and play, promotes interaction among children, and provides an authentic learning experience (McManis \& Gennewig, 2012; National Association for the Education of Young Children \& The Fred Rogers Center, 2012; Plowman et al., 2012; Rosen \& Jaruszewicz, 2009). Rosen and Jaruszewicz (2009) introduced the term developmentally appropriate technology use (DATU) which includes preparing a technology environment in early childhood settings that 
supports child-initiated learning, encourages collaborative problem solving, and takes a play-based, inquiry orientation.

The purpose of this study was to conduct a current review of the literature (2009-2014) to explore the impact of digital technologies in early childhood education environments for children aged 3 to 6 years.

\section{Previous Literature Reviews}

Four previous literature reviews have been conducted focusing on early childhood education and technology (Burnett, 2010; Lankshear \& Knobel, 2003; McCarrick \& Li, 2007; Yelland, 2005). A fifth review, conducted by Chantry \& Dunford (2010), was excluded because the age range of the children was not specified and the primary focus was on assistive technology, an area outside the scope of our paper. Each of these reviews will be discussed in turn.

The first review (Lankshear \& Knobel, 2003), focused on the use of technology and literacy development by young students ( 0 to 8 years old). Lankshear \& Knobel (2003) examined 22 articles, six reviews, and nine research reports from 1996 to 2002 . Overall, the results indicated either a positive relationship or no relationship between technology use and literacy skills. The authors noted the importance of key mitigating variables such as the use of non-interactive vs. interactive software, and the diversity of learners. They suggested that their review not only affirmed that technology use in early childhood and literacy was under-researched, but that the research that did exist was one-sided in that it focused on areas of reading/receiving rather than writing/generating. Lankshear and Knobel (2003) strongly recommended further research into new technologies in early childhood education which focus on the higher level literacy skills.

The second review (Yelland, 2005) examined research on young children, up to eightyears old, from 1994 to 2004, and provided a conceptual perspective (as opposed to a detailed, evidence-based analysis) on four domains (literacy, numeracy, creativity, and critical thinking) and the creation of knowledge building communities. Yelland (2005) began by outlining the arguments against the use of technology in early childhood settings (such as poor quality software, minimized role of teachers, social isolation, concepts being too abstract). She suggested that the research revealed that innovation is possible when technology use is embedded in new curricula and that young children can use technology to experience concepts that were previously well beyond them. She recommended that future research should focus on innovative uses of technology, rather than a replication of previous studies. She argued that simply comparing computer to non-computer contexts does not help to stimulate new understandings or add to knowledge of innovative uses of technology.

The third review, conducted by McCarrick and Li (2007) looked at research (19842004) on the impact of technology on four domains of development (social, cognitive, language development, and motivation) in children, three to five years old. Their findings indicated that social interactions among children are higher when computers are used. They also cited support for using computers to help scaffold children's learning (either with an adult, peer, or computer assisted scaffolding). McCarrick and Li (2007) also noted 
computers are highly motivating for preschoolers. Finally, they reported that the research does not show an improvement in language skills with computer use, nor was it found to be a hindrance. They suggested that further research be conducted using larger sample sizes, well-defined learning environments, and multiple developmental domains.

The final review, conducted by Burnett (2010), examined 34 peer-reviewed articles from 2003-2009 focusing on the use technology to promote print-based literacy for children within the $0-8$ age group. These articles were divided into three categories: technology as deliverer of literacy, technology as a site for interactions involving texts, and technology as a medium for meaning-making. Technology as a deliverer of literacy ( $\mathrm{n}=22$ studies) had either a positive impact on various language skills, motivation, and engagement, or no impact at all. Technology as a site for interactions ( $n=4$ studies), suggested that children interact positively with each other when they work together using digital texts or literacy software. Finally, technology as a medium for meaning-making ( $\mathrm{n}=10$ studies) is particularly successful when connected with the real world. Burnett (2010) highlighted the need for more extensive research into the area of children's engagement with digital texts. She acknowledged that most studies in her literature review were small-scale in terms of sample sizes, and narrowly focused. She suggested that a broader perspective should be taken when conducting research with young children to allow for the potential of identifying new possibilities and connections.

\section{Limitations of Previous Literature Reviews}

There are at least four issues with the four previous literature reviews which indicate the need for an updated review. First, three of the four literature reviews (Lankshear \& Knobel, 2003; McCarrick \& Li, 2007; Yelland, 2005) examined studies conducted ten or more years ago, while one review (Burnett, 2010) investigated studies conducted more than five years ago. In the field of technology, the landscape changes rapidly and it is important to consider new technological tools.

Second, three of the four reviews (Burnett, 2010; Lankshear \& Knobel, 2003; Yelland, 2005 ) focused on the 0 to 8 age group which represents children at very different stages of development. According to Piaget's Theory of Cognitive Development, children aged 0-2 years are at the sensorimotor stage, children aged 2-7 years are in the preoperational stage, and children aged 7-11 years are concrete operational (Piaget \& Inhelder, 1969). There is evidence that children think and behave differently at each of these stages and therefore may behave differently with technology. Piaget noted that children in the preoperational stage think intuitively and conceptually, but not logically. They also have difficulty seeing different points of view. On the other hand, children in the concrete operational stage are able to think more logically and they begin to recognize varying perspectives (Piaget \& Inhelder, 1969). Limiting the current study to the 3-6 age group might help reduce the variability in reported research findings and provide more reliable conclusions.

Third, two of the reviews (Burnett, 2010; Lankshear \& Knobel, 2003) had a singular focus in the domain of literacy. Broadening the scope to include research on a wider range of subject areas would provide a more holistic view of technology in early childhood education. 
Finally, all four reviews of the literature (Burnett, 2010, Lankshear \& Knobel, 2003; McCarrick \& Li, 2007; Yelland, 2005), while detailed and highly informative, had some issues with methodology, including not reporting strategies for locating and selecting articles (Yelland, 2005), omitting the number of articles assessed (McCarrick \& Li, 2007; Yelland, 2005), reviewing articles that were not peer-reviewed (Lankshear \& Knobel, 2003; McCarrick \& Li, 2007; Yelland, 2005), and failing to consistently provide summary details for sample size and description (Burnett, 2010; Lankshear \& Knobel, 2003; McCarrick \& Li, 2007; Yelland, 2005).

\section{Purpose}

The purpose of the following literature review was to analyze peer-reviewed studies on the use of technology by students in early childhood education settings from 2009-2014, with a focus on children aged 3-6 years.

\section{METHOD}

\section{Procedure}

This review focused on studies of technology use in early childhood educational settings published from 2009 to 2014. Only peer-reviewed articles that collected and analyzed data (not project descriptions, analyses of programs, guidelines for practice, reports, or conference papers), were included in this review. Well-known educational databases including EBSCOhost, Scholar's Portal, EdiTLibrary, and ERIC were searched based on the following age group keywords: "kindergarten," "early childhood," "preschool," "early years," and "young children," combined with the following technology-based keywords: "technology," "computers," "information communication technology," "ICT," "multimedia," and "digital." It is important to note that early childhood settings included the age group 36 years in preschool as well as Kindergarten classes. Kindergarten starts at various ages in different countries, and limiting the review to "kindergarten" would miss relevant research papers. This is why "preschool" was also included as a search term.

Titles and abstracts of articles found were screened for relevance. Specifically, formal research papers that directly assessed the use and impact of technology for the 3-6 age group were selected. The next step was to scrutinize the references of each article selected for further relevant articles. The search uncovered 30 peer-reviewed articles published from 2009 to 2014.

\section{Description of Studies Examined}

Year of study. Over $80 \%$ of the studies examining student use of technology occurred in $2009(n=6), 2010(n=4), 2001(n=8)$, and 2012 (n=7). Research in student use of technology in early childhood settings appears to drop off after 2012, with four studies in 2013 and only one study in 2014.

Sample population. Descriptions of sample data collected in this literature review were rated as limited, partial, or complete. "Limited" meant that little to no description was given of the sample. "Partial" meant that the size and some general characteristics were given (e.g., age, gender), while a "Complete" description meant that this information, in addition to 
further details, was given (e.g., socio-economic status, information about income and education level of parents, neighborhood). Seven studies gave a complete sample description (24\%), 19 gave a partial description (63\%), and four gave a limited description $(13 \%)$.

Eleven countries were represented in the literature review, including Australia $(n=1)$, Canada $(n=1)$, Greece $(n=4)$, Israel $(n=5)$, Jordan $(n=1)$, Korea $(n=1)$, Netherlands $(n=2)$, Norway ( $n=1)$, Taiwan $(n=1)$, UK ( $n=5)$, and USA ( $n=8)$.

The majority of studies focused on kindergarten students ( $n=29,97 \%)$ with five studies $(17 \%)$ looking at preschool and four studies (13\%) targeting Grade 1. Twelve studies (40\%) examined students who were at risk in some way, including low socioeconomic status, learning disability or developmental delay, at risk for learning disability, low performers, and disadvantaged $(\mathrm{n}=1,3 \%)$.

Method. In terms of methodological approach, eight studies (27\%) collected qualitative or descriptive data, 13 studies (43\%) used quantitative methods, and nine studies (30\%) used a mixed data collection approach. Sample sizes varied from three to 396, with almost $50 \%$ of the studies examining fewer than 30 children, and an average of 62 (SD=82) participants per study.

With respect to the quality of data collection, even studies $(23 \%)$ offered validity estimates, and three studies (10\%) presented both reliability and validity metrics (Couse \& Chen, 2010; Shamir, Korat, \& Shlafe, 2011; Shamir, Korat, \& Fellah, 2012).

Technology used. The studies in this review examined stand-alone software $(n=9$, $30 \%)$, e-books ( $\mathrm{n}=6,20 \%)$, hands-on technology devices such as interactive whiteboards or robotics $(n=6,20 \%)$, and online resources $(n=5,17 \%)$. Four studies $(13 \%)$ did not clearly specify the type of technology used. Two-thirds of the studies provided precise details about how the specific software or technology was used, whereas one third of the studies were more noticeably vague.

Focus of study. The studies in this review focused on literacy $(n=16,53 \%)$, engagement $(n=8,27 \%)$, social interactions $(n=7,23 \%)$, and mathematics $(n=3,10 \%)$. In addition, a set miscellaneous topics $(n=5,17 \%)$ included sequencing, visual perception, creative thinking, and fine motor capability. Ten studies (33\%) had multiple foci.

\section{Data Analysis}

Each study in this paper was coded and analyzed based on the following factors: year of study, country, sample population, subject area, sample size, sample description, type of data collection used, reliability, validity, focus on learning, and focus on engagement. See Appendix A for a list of the coded articles.

An abbreviated meta-analysis of effect size was conducted, but should be interpreted with caution for at least three reasons. First, the focus of the studies, method of data analysis, and subject area varied considerably, making it difficult to compare studies on a common metric in a meaningful way. Second, the reliability and validity of data collection tools were reported infrequently and inconsistently, thereby reducing confidence in quantitative 
results reported. Third, only 12 studies (40\%) provided enough data to calculate effect size for a total of 33 measures. A majority of studies provided insights into the use of technology in early childhood education using a qualitative $(n=8,27 \%)$ or mixed methods design $(n=9$, $30 \%)$.

\section{RESULTS AND DISCUSSION}

\section{Overview}

A review of the literature, based on the 30 peer-reviewed articles was organized into five main themes based on the primary focus of a study: literacy, engagement, social interactions, mathematics, and miscellaneous topics. Each of these themes will be discussed in turn. Next, an analysis of effect-size will be presented, based on 12 of the 30 articles reviewed. Effect-size was used to quantify the magnitude of difference between pre- and post-tests in these 12 studies. Finally an examination of methodology, and recommendations for future research will be offered.

\section{Impact of Technology on Literacy Learning $(n=16)$}

This theme included 16 studies (53\%) that described the use of technology to support the development of a wide range of literacy skills, including phonological awareness $(n=11)$, vocabulary development $(n=4)$, general literacy $(n=3)$, concepts of print $(n=2)$, and reading comprehension $(\mathrm{n}=2)$. Of these 16 studies, several address multiple and overlapping literacy skills which accounts for the total of 21 results reported.

Phonological awareness ( $\boldsymbol{n = 1 0 ) . ~ T e n ~ s t u d i e s ~ ( 3 3 \% ) ~ a d d r e s s e d ~ p h o n o l o g i c a l ~}$ awareness or the "ability to analyze the sound structure of language" (Macaruso \& Rodman, 2011, p. 172). Specific sub-skills of phonological awareness include the ability to break words into syllables and smaller units of sound, as well as the ability to blend the sounds back together (Maracuso \& Rodman, 2011). Five studies examined e-books (Korat, 2009; Korat, Shamir, \& Arbiv, 2011; Shamir, 2009; Shamir et al., 2012; Wood, Pillinger, \& Jackson, 2010), three studies used computer-assisted instruction (Comaskey, Savage, \& Abrami, 2009; Macaruso \& Rodman, 2011; Volpe, Burns, DuBois, \& Zaslofsky, 2011), one study employed interactive whiteboards (Campbell \& Mechling, 2009), and one study looked at online resources (Penuel et al.,2012).

All five e-book studies reported significant gains in phonological awareness. Shamir (2009), examining 96 children (5-6 years old) with low SES backgrounds, reported significant gains in emergent literacy after using e-books. Specifically, frequent activation of e-book hotspots (dictionary, phonological awareness, and pictures) was significantly correlated with improvements in understanding word meanings, whereas collaborative talk (among participants) was significantly correlated with increased phonological awareness. Korat (2009) observed that the phonological awareness and reading ability of 107 children (4 to 5 years old) significantly improved after five, 20-25 minute e-book sessions when compared to the control group. Korat et al., (2001) added children (aged 5 to 6) who used e-books with adult support over four, 20-minute sessions, performed significantly better than the control group on measures of opening and closing sounds, as wells as word writing. 
Shamir et al. (2012) examined the use of e-books with children (5 to 7 years) and observed significant improvements in sub-syllabic segmentation compared to control groups. Finally, Wood et al. (2010), when investigating the use of e-books with kindergarten children, noted that there were situations when e-books may be more effective (e.g., with early readers) and situations when adult-led instruction is better (e.g., with more advanced readers).

All three studies using computer-aided instruction reported significant gains in phonological development. Comaskey et al. (2009) noted that 53 disadvantaged kindergarten students showed significant improvements in consonant-vowel word blending, articulation of final consonants, and articulation of shared rime as a result of using a program called ABRACADABRA. Macaruso \& Rodman (2011) observed that pre-school students, who experienced 200 minutes of the Early Reading computer program had significantly greater gains in phonological awareness (sound matching and rhyming) than the control group. They also reported, in a second study, that low-performing kindergarten students ( 5 to 6 years old) who used the Early Reading and Primary Reading computer programs, attained significantly higher scores on phonological awareness than the control group. Finally, Volpe et al. (2001), in a small case study involving four at-risk kindergarten children, noted gains of six to nine letter sounds after using a Tutoring Buddy three times per week for a total of 25 sessions.

Campbell \& Mechling (2009), in a case study involving three kindergarten children who had learning disabilities, examined the effectiveness of a program used with an interactive whiteboard (IWB) targeting phonological awareness. After experiencing 34 sessions of 1015 minutes each, all three students increased their letter-sound knowledge.

Finally, in a large-scale study involving 396 pre-school children from 80 different classes, Penuel et al. (2012) reported that an intervention group who was exposed to PBS online videos and games scored significantly higher than the control group on letter sound awareness, letter name knowledge, and print concepts.

Six of the 10 studies examining the impact of technology on phonological awareness provided 14 measures with an average effect size of $0.52(S D=0.40)$. According to Hattie (2012), effect sizes between 0.03 and 0.6 are considered medium. It is reasonable to conclude, based on both quantitative and qualitative evidence, that the use of e-books, CAI programs, interactive whiteboards, and online resources can result in statistically significant moderate gains in the level of phonological awareness in young children, four to six years old.

Vocabulary $(\boldsymbol{n}=4)$. The second literacy category, vocabulary development, included four studies (13\%) in the areas of e-books and robotics (Korat, 2009; Shamir et al, 2011; Shamir et al., 2012; McDonald \& Howell, 2012).

Korat (2009) reported kindergarten children from low SES backgrounds, exposed to five, 20-25 minute e-book sessions progressed significantly more in vocabulary than the control group. Shamir et al. (2012), studied 100 children who were at risk, and observed that six, 20-35 minute e-book sessions produced significantly higher vocabulary scores than printed-book or control groups. Finally, Shamir et al. (2011) compared the vocabulary development of 60 typically developing kindergarten students with 76 kindergarten 
students at risk for a learning disability (aged 5-7) with the use of e-books. Both e-book groups scored significantly higher than the control groups on vocabulary. In addition, the at-risk group scored significantly higher than the typically developing group, which suggested that e-books might be a way to help close the gap in vocabulary development between these two groups.

Macdonald \& Howell (2012) used a robotics program to investigate vocabulary development in 16 children, ages 5.5 to 7 years, from low SES backgrounds. After completing six, 60-90 minute sessions over six weeks, students showed improvement in the use of vocabulary related to the use of robotics.

Based on results of three studies and five measures of vocabulary, the average effect size on vocabulary scores after using e-books was $1.18(S D=0.73)$. This is considered a high effect size according to Hattie (2012); however, the number of studies and the range of technology used focused exclusively on vocabulary skill.

General literacy ( $n=3)$. Three studies examined the impact of technology on general literacy, including emergent reading, writing, and/or oral language skills (Cviko, McKenney, \& Voogt, 2011; Huffstetter, King, Onwuegbuzie, Schneider, \& Powell-Smith, 2010; McKenney \& Voogt, 2009). McKenney \& Voogt (2009) examined the impact of PictoPal, a program that combines the use of pictures and words to enable students to express themselves in print, even before they are able to read. Students who used PictoPal for eight, 20-minute sessions over five weeks with adult support experienced significantly higher gains in early literacy skills than the control group. McKenney \& Voogt (2009) noted that the type of adult support had an effect of student learning, and that parent volunteers may need training to learn how to best support students when using PictoPal. Cviko et al. (2011) observed that children (age 3 to 5 years), working with the PictoPal program for 10-15 minutes per week for eight weeks with the help of grade 6 children, showed significantly higher gains in emergent literacy compared to the control group. Finally, Huffstetter et al. (2010), examining the Headsprout Early Reading computer program with children (4 to 6 years old) from low SES backgrounds, noted that reading ability, but not oral language skill, significantly increased for the intervention group compared to the control group. There are too few studies examining the impact of technology on general literacy skills to confirm whether there is a significant impact; however, the preliminary evidence suggests that PictoPal, and to a lesser extent, the Headsprout Early Reading, resulted in moderate improvements with an average effect size of $0.39(S D=0.46)$

Concept of print ( $n=2)$. Two studies (7\%) focused on concepts of print, which Shamir et al. (2012) describes as "A knowledge of book and text handling as well as the direction in which reading proceeds" (p. 55). In the first study, Levy (2009) was interested in exploring if children would develop concepts of print through a computer format just as well as with an actual book. She followed 12 children ( 3 to 6 years old) over the course of a year in their home and at their school. Levy (2009) found that exposing children to computer texts allowed them to develop confidence in handling print. With paper text, these children did not appear to have the same confidence, and believed they needed to be taught how to do it. Levy (2009) concluded that using computer texts allowed children to develop a sense of print in a holistic context better than paper texts. In the second study, Shamir et al. (2012), 
examined 100 children who were at risk, and reported that students experiencing six, 20-35 minute e-book sessions on their own, did not differ significantly from students who read print books with an adult on their concepts of print. The researcher notes that the use of ebooks to develop concepts of print could be particularly valuable when there is a lack of adult availability to read books. Overall, based on just two studies, there is limited evidence to suggest that technology can help improve concepts of print.

Reading compression ( $n=2)$. Two studies examined reading comprehension. Shamir et al. (2011) compared the use of e-books of 76 at-risk kindergarteners with 60 typical kindergarteners. E-books were used for six sessions of 20-35 minutes in length. The typically developing kindergarteners scored significantly higher than the at-risk group in terms of reading comprehension. However, both groups scored quite low, which led the researchers to suggest that comprehension might be taught more effectively with some adult support. Korat's (2009) study focused on the use of e-books with 107 pre-kindergartners and 108 kindergarteners of low SES. Children received either three or five sessions with the e-books (20-25 minutes each). No difference between the groups was found in terms of reading comprehension. However, age differences were found. Kindergarten aged children did better than the pre-kindergarten aged children, suggesting a developmental aspect to reading comprehension and the use of e-books. More research is needed with respect the use of technology and reading comprehension in order to make reliable and valid conclusions.

\section{Impact of Technology on Engagement $(n=8)$}

Eight studies (27\%) focused on the impact of technology on student engagement in early childhood education. Although many definitions exist for the term engagement; for the purposes of this paper, engagement refers to sustained involvement in learning activities, accompanied by interest and enjoyment (Parsons \& Taylor, 2012).

Six studies indicated that technology appears to increase engagement. Howard et al. (2012) reported that use of Smartboards and a computer lab by young children, over 39 sessions, resulted in moderate to high Leuven engagement scores. McDonald \& Howell (2012) noted that students from low SES backgrounds had higher levels of motivation and engagement after participating in a robotics program for six weeks (6.5 hours). Fesakis et al. $(2011,2013)$ observed in two small case studies, anecdotally, that students (5 to 6 years) using an online program called Monster Exchange or basic programming skills appeared highly engaged and motivated. Papadimitriou et al. (2013) explored digital storytelling over a period of three weeks with 19 children (5-6 years old) and reported that children were engaged and motivated throughout all of the activities. Roberts-Holmes (2014) added that preschoolers engaged in the collaborative creation of mini-movies were highly engaged. Two studies noted that the level of engagement increased with the age of the student (Couse \& Chen, 2010; Cviko et al., 2011).

Although all eight studies reported a positive relationship between engagement and technology use, each study was somewhat vague about precisely defining and measuring behaviors that indicate engagement. Of the eight studies reported, four studies used a quantitative tool to measure engagement (rating scale, length of time, checklist, and student 
survey); however, the reliability and validity for these measures were not reported. The remaining four studies used anecdotal evidence and observations with relatively small sample sizes to report engagement and none of the studies incorporated a control group. Therefore, the evidence that technology increases engagement for young children needs to be treated with caution.

\section{Impact of Technology on Social Interaction $(n=8)$}

Eight studies $(27 \%)$ focused on social interactions of children involving the use of technology. Two studies concentrated on social interactions and robotics programming (McDonald \& Howell, 2012; Lee, Sullivan, \& Bers, 2010), three studies examined social interactions occurring around the computer in the classroom (Lim, 2012; Roberts-Holmes, 2014; Wild, 2011), and the remaining three studies looked at social interactions when specific technology or software programs were used (Sandvik, Smordal, \& Osterun , 2012; Papadimitriou, Kapaniaris, Zisiadis, \& Kalogirou, 2013; Fesakis, et al., 2011).

Two studies indicated that the use of robotics programming appeared to increase social interaction. McDonald \& Howell (2012) used a robotics program with 16 children of low SES over the course of six weeks (6.5 hours) and found that social skills of students improved regarding students' ability to interact socially with their peers in the form of turn-taking, sharing ideas, and comfort level working in groups. Lee et al. (2010) examined the use of the Creative Hybrid Environment for Robotic Programming (CHERP) by children in a fiveday summer program (5 to 6 years), and reported that unstructured groups engaged in significantly more social interactions and peer collaborations than children in the structured group.

Three studies suggested that interactions around the computer increased social interaction. In the first study, Roberts-Holmes (2014) tracked sustained shared attention (SSA) and sustained shared thinking (SST) in 15 preschoolers (4 to 6 years). Qualitative observations indicated that when "playing" together on the computer, children tended to have a higher level of SSA. However, when engaged in a more constructive activity, such as making mini-movies, children engaged in a higher level of SST. In the second study, Wild (2011) observed that children ( 5 to 6 years) who participated in computer tasks over a one week session had a greater number of SSA and SST incidents than children who engaged in paper and pencil interactions during the same time period. Finally, Lim (2012) noted that in the computer area, collaborative learning occurred $68 \%$ of the time whereas in the other activity areas in the classroom, children (5 to 6 years) worked collaboratively for $54 \%$ of the time.

The remaining three studies examined the use of specific types of technology or programs and social interactions. Sandivik et al. (2012) anecdotally observed that five children using iPads ${ }^{\odot}$ (See and Say \& Puppet Pals) helped each other in both partner and full group activities, by cooperating, sharing, and participating. Papadimitriou et al. (2013) found that digital storytelling increased the number of both child-to-child and child-toteacher social interactions over the course of a three-week intervention using a digital camera, webcam, and computer. Finally, Fesakis, et al. (2011) noted an improvement in 
collaboration skills among the children (5 to 6 years) over the course of working with an online program called Monster Exchange (creating and giving directions to build a monster).

All eight studies reported that technology had a positive impact on social interaction among young children in the classroom; however, the results should be treated with caution for at least two reasons. First, reliability or validity measures used to assess social interaction were not provided for six of the eight studies. Second, six of the eight studies had a sample size less than 20. More research is needed to explore the specific details of social interactions and confirm whether the results are generalizable.

\section{Impact of Technology on Learning Mathematics $(n=3)$}

In contrast to the number of studies focusing on literacy ( $n=16,53 \%)$, only three studies (10\%) focused on mathematics related concepts. One study was based on robotics (McDonald \& Howell, 2012), while the other two examined specific online programs (Fesakis, Sofroniou, \& Mavroudi, 2011; Fessakis, Gouli, \& Mavroudi, 2013). McDonald \& Howell (2012), anecdotally observed that a robotics program improved numeracy skills for 16 children, age 5 to 7 years, with low SES backgrounds (e.g., ability to count, identify colors and shapes, and use of positional language). Fesakis et al. (2011), based on qualitative analysis, noted that an online program called Monster Exchange improved geometry skills for four children (5 to 6 years). Finally, Fessakis et al. (2013), through qualitative analysis of video recordings, reported that basic programing software, designed to move a digital ladybug through a maze, supported development of mathematical skills (one-to-one correspondence, counting, number comparison, orientation skills, and angle turn concepts) for 10 kindergarten students. In summary, all three studies indicated that technology, in various forms, helped improve mathematical skills. The exclusive use of qualitative evidence and small samples reduces the import of the findings. More research on a wider range of technologies and mathematical skills, combined with larger sample sizes is needed to confirm existing results.

\section{Impact of Technology - Miscellaneous Topics $(n=5)$}

Five studies (17\%) did not clearly fit into any distinct categories. These studies examined sequencing (Kazakoff \& Bers, 2012), visual perception (Chen, Lin, Wei, Liu, \& Wuang, 2013), creative thinking (Shawareb, 2011), and the fine motor capability of children to physically navigate a specific technological tool (Panagiotakou \& Pange, 2010; Couse \& Chen, 2010).

Kazakoff \& Bers (2012) explored the use of a robotics program and sequencing skills, an important component in the development of early math and early literacy learning. The results showed that the intervention group, which received 20 hours of lessons from the TangibleK robotics program, showed significant improvement in sequencing skills compared to the control group. Chen et al. (2013) studied the use of multimedia training for children with developmental delays, and reported significant gains for the intervention group in visual perception skills when compared to the control group. They also found that group multimedia training had a greater effect than individual multimedia training. Shawareb (2011) reported that children exposed to a wide array of computer standalone 
programs (Millie's Math House, Bailey's Book House, Sammy's Science House, KidPix, Dr. Seuss's ABC, Thinking' Things I) for 12 weeks scored significantly higher on a creative thinking test than the control group. Panagiotakou \& Pange (2010) reported that four to six year old students performed significantly better on a music activity using a camera mouse as opposed to a regular mouse, even though the former was more challenging to use. They speculated that the extra challenge and novelty of using the camera mouse resulted in a higher level of interest and concentration. Finally, Couse \& Chen (2010) examined the viability of using tablets with young children (3 to 6 years) to draw self-portraits, and observed that $64 \%$ of children preferred using technology over traditional materials. Some of the reasons children gave for this preference was that it was easier to draw on; the colors were brighter; and it was easier to erase and change things.

Previous research reviews (Burnett, 2010; Lankshear \& Knobel, 2003) and most of the studies in the current review suggest that the vast majority of research in technology and early childhood education focusses on literacy skills. However, the eclectic, yet positive use of technology in the above five studies suggests that there may be a much broader range of potential benefits for using technology with younger children.

\section{Effect Size}

Twelve studies (40\%) from this review provided enough data to calculate effect size for 33 measures. While the sample is small, several patterns emerged. First, the average effect size for all measures range from 0 to 2.38, with an average of $0.71(S D=0.60)$. According to Hattie (2012) who has conducted over 900 meta-analyses in the field of education, effect sizes over 0.60 should be considered seriously when selecting meaningful interventions for younger children. Therefore, the use of technology in the 12 quantitative studies reported in this review appear to have an educationally meaningful impact. Second, effect size for this small group of studies was higher when technology was used with students in the traditional stream $(\mathrm{n}=11,0.89, S D=0.65)$ than with students who were at-risk $(\mathrm{n}=22,0.63, S D=0.57)$. However, the magnitude of both effect sizes is meaningful according to Hattie (2012). Third, the type of technology used produced different effect sizes, with stand-alone tools producing the highest effect size $(\mathrm{n}=13,1.02, S D=0.69)$, e-books, the second highest effect size $(\mathrm{n}=14$, $0.60, S D=0.49)$, and online resources, the smallest effect size $(\mathrm{n}=6,0.30, S D=0.15)$. Again, the sample effect size was small, and more research is needed to determine why this difference might occur, and whether it is consistent. Fourth, not enough effect sizes were available to compare age groups or skill type targeted (e.g., literacy, mathematics, social interaction, engagement).

\section{Methodological Challenges}

The 30 papers from 2009-2014 that have been reviewed present some interesting and useful findings. However, it is important to address several key methodological concerns, including sample size and description, reliability and validity of data collection tools, and pedagogy and design issues, that may affect the credibility of the results.

Sample size. Sample size varied according to the intended purpose of a particular study. In the current literature review, 12 studies (40\%) had sample sizes over 50, which permits 
a certain degree of generalization when reporting results. On the other hand, seven studies (23\%) had samples sizes between 20 and 50, and 12 studies (20\%) had sample sizes of less than 20 students. Sample sizes of less than 30 are generally considered small (Onwuegbuzie \& Leech, 2010), although there is some disagreement about the potential impact. Nikolopoulou (2010), argued that even though sample sizes may be small, when research involves young children, the results, in general, are not easily generalizable, regardless of sample size. Furthermore, small sample qualitative studies can offer valuable detailed information about the behaviours, processes, and phenomena observed in early childhood education settings. Regardless, it is important when considering the results of this literature review to note that over half of the studies had relatively small sample sizes.

Sample descriptions. Over three quarters of the studies examined in this review provided partial or incomplete descriptions of the sample participants. However, factors such as gender, cognitive ability, socio-economic status, education level of parents, type of disadvantage, or educational risk can have a significant impact on the influence that technology has on learning and engagement. In addition, providing complete, detailed information, makes it easier to systematically compare studies.

Reliability and validity. Reporting of reliability and validity metrics in review of literature was inconsistent and limited. Only three quantitative/mixed methods studies provided estimates of both reliability and validity of data collections tools. Three of the eight qualitative studies (38\%) explained how they achieved aspects of reliability in their studies. They addressed inter-rater reliability by having more than one person independently rate/code/organize observations, video recordings, and/or transcripts. Of the remaining five qualitative studies, three did not mention reliability or validity, while two acknowledged and explained the limitations and challenges of their study. Clearly, it is important to provide some form of data collection quality, regardless of the design used, in order to have confidence in the consistency and accuracy of the results.

Pedagogy. Overall, the studies assessed in this review were relatively rigorous about reporting pedagogy used. In 23 studies (76\%), the details of the technology and the basics for how it was used were clear. Whether the technology was used independently, in partners, small groups, or with an adult, was mentioned in 20 studies (67\%). However, the role of the adult was rarely explained clearly. It is important to understand how the adult engaged with the child or children working with the technology, as the level of support could affect the results. Explicit details about the teaching strategies used with technology are critical for understanding the impact of a particular device in a specific environment. Key factors such as interactivity, collaboration, problem solving, scaffolding provided, and creativity, can markedly alter the impact of a specific technology.

Use of technology. The majority of studies in the current review used stand-alone technology in the form of software, CD-ROMS, and e-books. This technology, while potentially useful, is dated, costly, and neither scalable nor sustainable in a larger context. Many school boards cannot afford to maintain technology solutions that required extensive technology support, upgrades, and dedicated hardware. Online technology, examined in only four studies, is a far more realistic and promising direction for technology use in early 
childhood education classes. There is an abundance of free, high quality online tools available to educators that can be used on a variety of devices.

Area of focus. Over $50 \%$ of the studies in this review focused on literacy skills, which is a key area of need in early childhood education (Lynch \& Redpath, 2014; Wohlwend, 2010; Yelland, 2011). However, the limited number of studies addressing mathematics skills is concerning. One research report noted that minimal gains have been made in improving mathematics skills for at-risk students over the past 40 years (Strong American School, 2008). Clearly, more research needs to focus on the use of technology to support mathematics skills.

\section{Limitations and Recommendations for Future Research}

All studies, regardless of methodology, age group, or technological device used, reported a positive effect of technology on learning or engagement. The impact of technology use on literacy development appears to be reasonably well established in the literature, particularly in the area of phonological awareness, and to a lesser extent, vocabulary and general literacy. Other areas of study, including the impact of technology on engagement, social interaction, and mathematical skills, showed a positive effect, but evidence was based on relatively few studies, small sample sizes, and qualitative observations. Clearly, researchers need to broaden the scope of technology interventions beyond literacy. They should also consider larger scale experimental studies, like some of those conducted in the domain of literacy, to see if the results in less studied areas are generalizable.

Specialized, stand-alone technology, and e-books, were used most often $(87 \%$ of the time). The availability of free, easy to use, online software provides a promising interactive environment and direction for future research on the use of technology in early childhood education.

While a number of studies used well-designed, carefully constructed methodologies; improvements could be made by providing clear, detailed descriptions of the participants; articulating parameters for assessing the quality of data collected, such as reliability and/or validity; and noting the role of an adult in offering support when the technology is used.

Overall, the results summarized in this literature review suggest that technology can have a positive influence on literacy development, engagement, social interactions, mathematics skills, sequencing, visual perception, creative thinking, and fine motor capability in young children. However, it is important to recognize that a wide variety of factors can, and do, moderate the impact of technology on educational outcomes, including who is using the technology (younger vs. older children, students at-risk); the type of technology use (desktop computers with specific programs, e-books, tablets, video cameras, interactive whiteboards, and robotics); how the technology is used (individually, partners, small groups); where the technology is used (within the classroom or online); what support is provided (independent use or with adult or older peer support); and whether supplemental materials are used (introductory lessons and print-based materials). Understanding the influence of multiple moderators, and employing a systems approach to 
the use of technology in education, is a challenging but a necessary step for conducting future research in order to provide meaningful and effective guidance to teachers and students.

\section{Conclusion}

This study reviewed 30 papers, from 2009 to 2014, examining the impact of digital technology used with children aged 3 to 6 years. Stand-alone software, CD-ROMS, and ebooks were used in the majority of studies. Four key content areas of focus emerged, including literacy, engagement, social interactions, and mathematics. Sixteen papers targeting the impact of technology on literacy skills revealed statically significant gains in phonological awareness, vocabulary, general literacy, reading compression, and the concept of print. Eight studies reported a positive relationship between the use of technology and engagement. Eight studies suggested that technology had a positive impact on social interactions like cooperating, sharing, and collaborating. Three studies indicated that technology helped to improve mathematics skills and the impact of technology on mathematics skills, such as numeracy skills, counting, and identifying shapes. The average effect size, based on only 12 studies, was 0.71 , indicating that the impact of technology for younger children was meaningful. Methodological limitations noted for the studies reviewed included small sample sizes; an absence of reliability and validity metrics for data collection instruments; the use of technology that is dated, costly, and neither scalable nor sustainable; and a disproportionate focus on literacy. 


\section{REFERENCES}

Alper, M. (2011). Developmentally appropriate new media literacies: Supporting cultural competencies and social skills in early childhood education. Journal of Childhood Literacy, 13(2), 175-196. doi: 10.1177/1468798411430101

Anderson, C. A., \& Bushman, B. J. (2001). Effects of violent video games on aggressive behavior, aggressive cognition, aggressive affect, physiological arousal, and prosocial behavior: A meta-analytic review of the scientific literature. Psychological Science, 12(5), 353-359. doi:10.1111/1467-9280.00366

Aubrey, C., \& Dahl, S. (2014). The confidence and competence in information and communication technologies of practitioners, parents and young children in the early years foundation stage. Early Years, 34(1), 94-108. doi:10.1080/09575146.2013.792789

Blackwell, C. (2013). Teacher practices with mobile technology integrating tablet computers into the early childhood classroom. Journal of Education Research, 7(4), 231-255.

Burnett, C. (2010). Technology and literacy in early childhood educational settings: A review of research. Journal of Early Childhood Literacy, 10(3), 247-270. doi: $10.1177 / 1468798410372154$

Campbell, M. L., \& Mechling, L. C. (2009). Small group computer-assisted instruction with SMART board technology. Remedial and Special Education, 30(1), 47-57. doi: $10.1177 / 0741932508315048$

Cassell, J. (2004). Towards a model of technology and literacy development: Story listening systems. Journal of Applied Developmental Psychology, 25(1), 75-105. doi:10.1016/j.appdev.2003.11.003

Chantry, J., \& Dunford, C. (2010). How do computer assistive technologies enhance participation in childhood occupations for children with multiple and complex disabilities? A review of the current literature. The British Journal of Occupational Therapy, 73(8), 351-365. doi: 10.4276/030802210X12813483277107

Chen, Y., Lin, C., Wei, T., Liu, C., \& Wuang, Y. (2013). The effectiveness of multimedia visual perceptual training groups for the preschool children with developmental delay. Research in Developmental Disabilities, 34(12), 4447-4454. doi:10.1016/j.ridd.2013.09.023

Chera, P., \& Wood, C. (2003). Animated multimedia 'talking books' can promote phonological awareness in children beginning to read. Learning and Instruction, 13(1), 33-52. doi: 10.1016/S0959-4752(01)00035-4

Cicconi, M. (2014). Vygotsky meets technology: A reinvention of collaboration in the early childhood mathematics classroom. Early Childhood Education Journal, 42(1), 57-65. doi: 10.1007/s10643-013-0582-9

Comaskey, E. M., Savage, R. S., \& Abrami, P. (2009). A randomised efficacy study of web-based synthetic and analytic programmes among disadvantaged urban kindergarten children. Journal of Research in Reading, 32(1), 92-108. doi: 10.1111/j.1467-9817.2008.01383.x

Couse, L. J., \& Chen, D. W. (2010). A tablet computer for young children? Exploring its viability for early childhood education. Journal of Research on Technology in Education, 43(1), 7598. doi: 10.1080/15391523.2010.10782562 
Cordes, C. \& Miller, E. (2000). Fool's gold: A critical look at computers in childhood. College Park, MD: Alliance for Childhood. Retrieved from http://files.eric.ed.gov/fulltext/ED445803.pdf

Cviko, A., McKenney, S., \& Voogt, J. (2012). Teachers enacting a technology-rich curriculum for emergent literacy. Educational Technology Research and Development, 60(1), 31-54. doi: $10.1007 / x 11423-011-9208-3$

Edwards, S. (2013). Digital play in the early years: A contextual response to the problem of integrating technologies and play-based pedagogies in the early childhood curriculum.

European Early Childhood Education Research Journal, 21(2), 199-212. doi:10.1080/1350293X.2013.789190

Fesakis, G., Sofrouniou, C., \& Mavroudi, E. (2011). Using the internet for communicative learning activities in kindergarten: The case of the "Shapes Planet." Early Childhood Education Journal, 39(5), 385-392. doi: 10.1007/s10643-010-0422-0

Fessakis, G., Gouli, E., \& Mavroudi, E. (2013). Problem solving by 5-6 years old kindergarten children in a computer programming environment: A case study. Computers \& Education, 63(4), 87-97. doi:10.1016/j.compedu.2012.11.016

Hattie, J. (2012). Visible learning for teachers: Maximizing impact on learning. New York: Routledge.

Healy, J. M. (2004). Young children don't need computers. Education Digest, 69(5), 57-58.

Hillman, M., \& Marshall, J. (2009). Evaluation of digital media for emergent literacy. Computers in the Schools, 26(4), 256-270. doi:10.1080/07380560903360186

Howard, J., Miles, G. E., \& Rees-Davies, L. (2012). Computer use within a play-based early years curriculum. International Journal of Early Years Education, 20(2), 175-189. doi:10.1080/09669760.2012.715241

House, R. (2012). The inappropriateness of ICT in early childhood education: Arguments from philosophy, pedagogy and developmental psychology. In S. Suggate \& E. Reese (Eds.), Contemporary debates in childhood education and development (pp. 105-121). New York: Routledge.

Huffstetter, M., King, J. R., Onwuegbuzie, A. J., Schneider, J. J., \& Powell-Smith, K. A. (2010). Effects of a computer-based early reading program on the early reading and oral language skills of at-risk preschool children. Journal of Education for Students Placed at Risk, 15(4), 279-298. doi:10.1080/10824669.2010.532415

Hutinger, P. L., \& Johanson, J. (2000). Implementing and maintaining an effective early childhood comprehensive technology system. Topics in Early Childhood Special Education, 20(3), 159-173. doi: 10.1177/027112140002000305

Kazakoff, E., \& Bers, M. (2012). Programming in a robotics context in the kindergarten classroom: The impact on sequencing skills. Journal of Educational Multimedia and Hypermedia, 21(4), 371-391.

Kirkorian, H. L., Wartella, E. A., \& Anderson, D. R. (2008). Media and young children's learning. The Future of Children, 18(1), 39-61.

Ko, C.H., \& Chou, M.J. (2014). Aesthetics in early childhood education: The combination of technology instruments in children's music, visual arts and pretend play. Journal of Social Sciences, 10(1), 39-45. doi: 10.3844/jssp.2014.39.45 
Korat, O. (2009). The effects of CD-ROM storybook reading on Israeli children's early literacy as a function of age group and repeated reading. Education and Information Technologies, 14(1), 39-53. doi: 10.1007/s10639-008-9063-y

Korat, O., Shamir, A., \& Arbiv, L. (2011). E-books as support for emergent writing with and without adult assistance. Education and Information Technologies, 16(3), 301-318. doi: 10.1007/x10639-010-9127-7

Lankshear, C., \& Knobel, M. (2003). New technologies in early childhood literacy research: A review of research. Journal of Early Childhood Literacy, 3(1), 59-82. doi: $10.1177 / 14687984030031003$

Lieberman, D. A., Fisk, M. C., \& Biely, E. (2009). Digital games for young children ages three to six: From research to design. Computers in the Schools, 26(4), 299-313. doi:10.1080/07380560903360178

Lee, K. T. H., Sullivan, A., \& Bers, M. U. (2013). Collaboration by design: Using robotics to foster social interaction in kindergarten. Computers in the Schools, 30(3), 271-281. doi:10.1080/07380569.2013.805676

Levy, R. (2009). 'You have to understand words ... but not read them': Young children becoming readers in a digital age. Journal of Research in Reading, 32(1), 75-91. doi: 10.1111/j.1467-9817.2008.01382.x

Lim, E. M. (2012). Patterns of kindergarten children's social interaction with peers in the computer area. International Journal of Computer-Supported Collaborative Learning, 7(3), 399-421. doi: 10.1007/s11412-012-9152-1

Lindahl, M. G., \& Folkesson, A. (2012). ICT in preschool: Friend or foe? The significance of norms in a changing practice. International Journal of Early Years Education, 20(4), 422436. doi:10.1080/09669760.2012.743876

Lynch, J., \& Redpath, T. (2014). 'Smart' technologies in early years literacy education: A metanarrative of paradigmatic tensions in iPad use in an Australian preparatory classroom. Journal of Early Childhood Literacy, 14(2), 147-174. doi: 10.1177/1468798412453150

Macaruso, P., \& Rodman, A. (2011). Efficacy of computer-assisted instruction for the development of early literacy skills in young children. Reading Psychology, 32(2), 172196. doi:10.1080/02702711003608071

Mama, M., \& Hennessey, S. (July 2010). Level of technology integration by primary teachers in Cyprus and student engagement. Technology, Pedagogy and Education, 19(2), 269275. doi: 10.1080/1475939X.2010.491238

McCarrick, K., \& Li, X. (2007). Buried treasure: The impact of computer use on young children's social, cognitive, language development and motivation. AACE Journal, 15(1), 73-95.

McDonald, S., \& Howell, J. (2012). Watching, creating and achieving: Creative technologies as a conduit for learning in the early years. British Journal of Educational Technology, 43(4), 641-651. doi:10.1111/j.1467-8535.2011.01231.x

McKenney, S., \& Voogt, J. (2009). Designing technology for emergent literacy: The PictoPal initiative. Computers \& Education, 52(4), 719-729. doi:10.1016/j.compedu.2008.11.013

McManis, L., \& Gunnewig, S. (2012). Finding the education in educational technology with early learners. Young Children, 67(3), 14-24. 
Morgan, A. (2010). Interactive whiteboards, interactivity and play in the classroom with children aged three to seven years. European Early Childhood Education Research Journal, 18(1), 93-104. doi:10.1080/13502930903520082

Muligan, S.A. (2003). Assistive technology: Supporting the participation of children with disabilities. Young Children, 58(6), 50-51. Retrieved from www.naeyc.org/files/yc/file/200311/AssistiveTechnology.pdf

National Association for the Education of Young Children \& The Fred Rogers Center. (2012). Technology and interactive media as tools in early childhood programs serving children from birth through age 8 . Washington, DC: Authors.

Nikolopoulou, K. (2010). Methods for Investigating Young Children's Learning and Development with Information Technology. In A. McDougall, J. Murnane, A. Jones, \& N. Reynolds (Eds.), Researching IT in Education: Theory, Practice and Future Directions (pp. 183-191). London: Routledge.

Onwuegbuzie, A. J., \& Leech, N. L. (2010). Generalization practices in qualitative research: A mixed methods case study. Quality and Quantity, 44(5), 881-892. doi:http://dx.doi.org/10.1007/s11135-009-9241-z

Panagiotakou, C., \& Pange, J. (2010). The use of ICT in preschool music education. Procedia Social and Behavioral Sciences, 2(2), 3055-3059. doi: 10.1016/j.sbspro.2010.03.464

Papadimitriou, E., Kapaniaris, A., Zisiadis, D., \& Kalogirou, E. (2013). Digital storytelling in kindergarten: An alternative tool in children's way of expression. Mediterranean Journal of Social Sciences, 4(11), 389-396. doi: 10.5901/mjss.2013.v4n11p389

Parette, H., Quensenberry, A., \& Blum, C. (2010). Missing the boat with technology usage in early childhood settings: A $21^{\text {st }}$ century view of developmentally appropriate practice. Early Childhood Education Journal, 37(5), 335-343. doi: 10.1007/s10643-009-0352-x

Parsons, J., \& Taylor, L. (2012). Student engagement: What do we know and what should we do? Edmonton, Alta: University of Alberta. Retrieved from https://education.alberta.ca/media/6459431/student engagement literature review 2011.pdf

Penuel, W. R., Bates, L., Gallagher, L. P., Pasnik, S., Llorente, C., Townsend, E.., Hupert, N., Dominguez, X., \& VanderBorght, M. (2012). Supplementing literacy instruction with a media-rich intervention: Results of a randomized controlled trial. Early Childhood Research Quarterly, 27(1), 115-127. doi: 10.1016/j.ecresq.2011.07.002

Plowman, L., \& Stephen, C. (2003). A 'benign addition'? Research on ICT and pre-school children. Journal of Computer Assisted Learning, 19(2), 149-164. doi: 10.1046/j.02664909.2003.00016.x

Plowman, L., \& McPake, J. (2013). Seven myths about young children and technology. Childhood Education, 89(1), 27-33. doi: 10.1080/00094056.2013.757490

Plowman, L., McPake, J., \& Stephen, C. (2012). Extending opportunities for learning: the role of digital media in early education. In S. Suggate \& E. Reese (Eds.), Contemporary debates in childhood education and development (pp 95-104). New York: Routledge.

Plowman, L., Stevenson, O., McPake, J., Stephen, C., \& Adey, C. (2011). Parents, pre-schoolers and learning with technology at home: Some implications for policy. Journal of Computer Assisted Learning, 27(4), 361-371. doi:10.1111/j.1365-2729.2011.00432.x 
Roberts-Holmes, G. (2014). Playful and creative ICT pedagogical framing: A nursery school case study. Early Child Development and Care, 184(1), 1-14. doi:10.1080/03004430.2013.772991

Rosen, D. B., \& Jaruszewicz, C. (2009). Developmentally appropriate technology use and early childhood teacher education. Journal of Early Childhood Teacher Education, 30(2), 162171. doi: $10.1080 / 10901020902886511$

Sandvik, M., Smordal, O., \& Osterud, S. (2012). Exploring iPads in practitioners' repertoires for language learning and literacy practices in kindergarten. Nordic Journal of Digital Literacy, $\quad 7(3), \quad 204-220 . \quad$ Retrieved from http://www.idunn.no/dk/2012/03/exploring ipads in practitioners repertoires for 1 anguage

Shamir, A. (2009). Processes and outcomes of joint activity with e-books for promoting kindergarteners' emergent literacy. Educational Media International, 46(1), 81-96. doi: $10.1080 / 09523980902781295$

Shamir, A., Korat, O., \& Fellah, R. (2012). Promoting vocabulary, phonological awareness and concept about print among children at risk for learning disability: can e-books help? Reading and Writing: An Interdisciplinary Journal, 25(1), 46-69. doi: 10.1007/s11145010-9247-x

Shamir, A., Korat, O., \& Shlafer, I. (2011). The effect of activity with e-book on vocabulary and story comprehension: A comparison between kindergarteners at risk of learning disabilities and typically developing kindergarteners. European Journal of Special Needs Education, 26(3), 311-322. doi:10.1080/08856257.2011.593824

Shawareb, A. (2011). The effects of computer use on creative thinking among kindergarten children in Jordan. Journal of Instructional Psychology, 38(4), 213-220.

Shifflet, R., Toledo, C. \& Mattoon, C. (2012). Touch tablet surprises. Young Children, 67(3), 3641.

Retrieved

from http://www.naeyc.org/yc/files/yc/Touch\%20Tablet\%20Suprises.pdf

Strong American Schools (2008). A stagnant nation: Why American students are still at risk. Retrieved from http://cdm16064.contentdm.oclc.org/cdm/ref/collection/p266901coll4/id/190

Turja, L., Endepohls-Ulpe, M., \& Chatoney, M. (2009). A conceptual framework for developing the curriculum and delivery of technology education in early childhood. International Journal of Technology and Design Education, 19(4), 353-365. doi:10.1007/s10798-0099093-9

Vernadakis, N., Avgerinos, A., Tsitskari, E. \& Zachopoulou, E. (2005). The use of computer assisted instruction in preschool education: Making teaching meaningful. Early Childhood Education Journal, 33(2), p 99-104. doi: 10.1007/s10643-005-0026-2

Volpe, R. J., Burns, M. K., DuBois, M., \& Zaslofsky, A. F. (2011). Computer-assisted tutoring: Teaching letter sounds to kindergarten students using incremental rehearsal. Psychology in the Schools, 48(4), 332-342. doi:10.1002/pits.20557

Wang, F., Kinzie, M., McGuire, P., \& Pan, E. (2010). Applying technology to inquiry-based learning in early childhood education. Early Childhood Education Journal, 37(5), 381389. doi: $10.1007 / \mathrm{s} 10643-009-0364-6$ 
Wild, M. (2011). Thinking together: Exploring aspects of shared thinking between young children during a computer-based literacy task. International Journal of Early Years Education, 19(3-4), 219-231. doi:10.1080/09669760.2011.629490

Wohlwend, K. (2010). A is for avatar: Young children in literacy 2.0 worlds and literacy 1.0 schools. Language Arts, 88(2), 144-152.

Wood, C., Pillinger, C., \& Jackson, E. (2010). Understanding the nature and impact of young readers' literacy interactions with talking books and during adult reading support. Computers \& Education, 54(1), 190-198. doi:10.1016/j.compedu.2009.08.003

Yelland, N. (2005). The future is now: A review of the literature on the use of computers in early childhood education (1994-2004). AACE Journal, 13(3), 201-232.

Yelland, N. (2011). Reconceptualising play and learning in the lives of young children. Australasian Journal of Early Childhood, 36(2), 4-12.

Youngquist, J., \& Pataray-Ching, J. (2004). Revisiting "play": Analyzing and articulating acts of inquiry. Early Childhood Education Journal, 31(3), 171-178. doi: 10.1023/B:ECEJ.0000012135.73710.0c 
Appendix A - List of Coded Articles

\begin{tabular}{|c|c|c|c|c|c|c|c|c|c|}
\hline Authors & Country & Pop & Theme(s) & Technology Used & $\begin{array}{c}\text { Sample } \\
\text { Size }\end{array}$ & $\begin{array}{l}\text { Sample } \\
\text { Desc. }\end{array}$ & $\begin{array}{l}\text { Type of } \\
\text { Data }\end{array}$ & $\begin{array}{c}\text { Scale } \\
\text { Reliable }\end{array}$ & $\begin{array}{l}\text { Scale } \\
\text { Valid }\end{array}$ \\
\hline $\begin{array}{l}\text { Campbell \& } \\
\text { Mechling, } 2009\end{array}$ & US & $\mathrm{K}$ & literacy, at-risk & $\begin{array}{l}\text { Interactive } \\
\text { Whiteboard }\end{array}$ & 3 & Partial & Quant & Yes & No \\
\hline Chen et al., 2013 & Taiwan & $\mathrm{K}$ & new areas, at risk & $\begin{array}{c}\text { Visual Perception } \\
\text { Training } \\
\text { (non-specific) }\end{array}$ & 64 & Complete & Quant & Yes & Yes \\
\hline $\begin{array}{l}\text { Comaskey et al., } \\
2009\end{array}$ & Canada & $\mathrm{K}$ & literacy, at risk & $\begin{array}{l}\text { ABRACADABRA } \\
\text { (online) }\end{array}$ & 53 & Partial & Quant & Yes & No \\
\hline $\begin{array}{l}\text { Couse \& Chen, } \\
2010\end{array}$ & US & Pre, $\mathrm{K}$ & new areas, engagement & $\begin{array}{l}\text { Drawing Software } \\
\text { (tablets and non- } \\
\text { specific) }\end{array}$ & 41 & Complete & Mixed & Yes & Yes \\
\hline Cviko et al., 2011 & Holland & $\mathrm{K}$ & literacy. engagement & $\begin{array}{c}\text { PictoPal } \\
\text { Curriculum } \\
\text { (non-specific) }\end{array}$ & 168 & Complete & Mixed & Yes & No \\
\hline $\begin{array}{l}\text { Fesakis et al., } \\
2011\end{array}$ & Greece & $\mathrm{K}$ & $\begin{array}{l}\text { mathematics, } \\
\text { engagement }\end{array}$ & $\begin{array}{l}\text { Monster Exchange } \\
\text { (online) }\end{array}$ & 4 & Partial & Qual & No & No \\
\hline $\begin{array}{l}\text { Fessakis, Gouli, \& } \\
\text { Mavroudi, } 2013\end{array}$ & Greece & $\mathrm{K}$ & $\begin{array}{l}\text { mathematics, } \\
\text { engagement }\end{array}$ & $\begin{array}{l}\text { Lady Bug } \\
\text { Programming } \\
\text { (online) }\end{array}$ & 10 & Limited & Qual & No & No \\
\hline $\begin{array}{l}\text { Howard et al., } \\
2012\end{array}$ & $\begin{array}{l}\text { UK } \\
\text { South } \\
\text { Wales }\end{array}$ & $\begin{array}{l}\text { Pre, } \mathrm{K}, \\
\text { Gr 1, T }\end{array}$ & engagement & $\begin{array}{c}\text { Tech-Based } \\
\text { Classrooms } \\
\text { (non-specific) }\end{array}$ & $\begin{array}{c}12 \\
\text { schools }\end{array}$ & Partial & Mixed & No & No \\
\hline $\begin{array}{l}\text { Huffstetter et al., } \\
2010\end{array}$ & US & $\mathrm{K}$ & Literacy, at risk (poverty) & $\begin{array}{c}\text { Headsprout Early } \\
\text { Reading Program } \\
\text { (online) }\end{array}$ & 62 & Complete & Mixed & Yes & Yes \\
\hline $\begin{array}{l}\text { Kazakoff \& Bers, } \\
2012\end{array}$ & US & $\mathrm{K}$ & new areas & $\begin{array}{c}\text { TangibleK Robotics } \\
\text { program } \\
\text { (hands on) }\end{array}$ & 54 & Complete & Quant & No & No \\
\hline
\end{tabular}




\begin{tabular}{|c|c|c|c|c|c|c|c|c|c|}
\hline Korat, 2009 & Israel & $\mathrm{K}$ & literacy, at-risk & e-books & 214 & Partial & Quant & Yes & No \\
\hline Korat et al., 2011 & Israel & $\mathrm{K}$ & literacy, at-risk & e-books & 96 & Complete & Quant & Yes & No \\
\hline Lee et al., 2013 & US & $\mathrm{K}$ & social interaction & $\begin{array}{l}\text { LEGO Mindstorms } \\
\text { (hands on) }\end{array}$ & 19 & Partial & Quant & No & No \\
\hline Levy, 2009 & UK & Pre, K & Literacy & $\begin{array}{l}\text { Computer texts } \\
\text { (non-specific) }\end{array}$ & 12 & Partial & Qual & Yes & Yes \\
\hline Lim, 2012 & Korea & $\mathrm{K}$ & social interaction & $\begin{array}{c}\text { Computer } \\
\text { Classroom } \\
\text { (non-specific) }\end{array}$ & 28 & Partial & Qual & No & No \\
\hline $\begin{array}{l}\text { Macaruso \& \& } \\
\text { Rodman, } 2011\end{array}$ & US & $\mathrm{K}$ & Literacy & $\begin{array}{l}\text { Early Reading } \\
\text { (stand-alone) }\end{array}$ & 38 & Partial & Quant & No & Yes \\
\hline $\begin{array}{ll}\text { McDonald } & \& \\
\text { Howell, } 2012 & \end{array}$ & Australia & $\mathrm{K}, \mathrm{Gr} 1$ & $\begin{array}{l}\text { literacy, mathematics, } \\
\text { social } \\
\text { engagement, at risk }\end{array}$ & $\begin{array}{l}\text { LEGO Robotics } \\
\text { WeDo } \\
\text { (hands on) }\end{array}$ & 16 & Partial & Mixed & No & No \\
\hline $\begin{array}{l}\text { McKenney \& } \\
\text { Voogt, } 2009\end{array}$ & Holland & K & Literacy & $\begin{array}{c}\text { PictoPal } \\
\text { Curriculum } \\
\text { (non-specific) }\end{array}$ & 14 to 79 & Partial & Mixed & No & No \\
\hline $\begin{array}{l}\text { Panagiotakou \& } \\
\text { Pange, } 2010\end{array}$ & Greece & K & new areas, engagement & $\begin{array}{c}\text { Regular vs. Camera } \\
\text { Mouse } \\
\text { (hardware) }\end{array}$ & 28 & Partial & Mixed & No & No \\
\hline $\begin{array}{l}\text { Papadimitriou } \\
\text { Kapaniaris et al. } \\
2013\end{array}$ & Greece & $\mathrm{K}$ & $\begin{array}{l}\text { social interactions, } \\
\text { engagement }\end{array}$ & $\begin{array}{l}\text { Digital Story } \\
\text { Telling Video } \\
\text { (hands on) }\end{array}$ & 19 & Limited & Qual & No & No \\
\hline Penuel et al.,2012 & US & Pre, $\mathrm{K}$ & literacy, at-risk & $\begin{array}{l}\text { PBS video \& games } \\
\text { (non -specific) }\end{array}$ & 396 & Complete & Quant & No & No \\
\hline $\begin{array}{l}\text { Roberts-Holmes, } \\
2014\end{array}$ & UK & Pre & $\begin{array}{l}\text { social interactions, } \\
\text { engagement }\end{array}$ & $\begin{array}{c}\text { Computer } \\
\text { Classroom } \\
\text { (non-specific) }\end{array}$ & 15 & Partial & Qual & Yes & No \\
\hline $\begin{array}{l}\text { Sandvik et al., } \\
2012\end{array}$ & Norway & $\mathrm{K}$ & social interaction & $\begin{array}{l}\text { See and Say and } \\
\text { Puppet Pals } \\
\text { (iPad Apps) }\end{array}$ & 5 & Partial & Qual & No & No \\
\hline
\end{tabular}




\begin{tabular}{|c|c|c|c|c|c|c|c|c|c|}
\hline Shamir, 2009 & Israel & $\mathrm{K}$ & literacy, at-risk & e-books & 96 & Partial & Mixed & Yes & No \\
\hline $\begin{array}{l}\text { Shamir et al., } \\
2012\end{array}$ & Israel & K, Gr 1 & literacy, at risk & e-books & 11 & Partial & Quant & Yes & Yes \\
\hline $\begin{array}{l}\text { Shamir et al., } \\
2011\end{array}$ & Israel & $\mathrm{K}, \mathrm{Gr} 1$ & literacy, at-risk & e-books & 136 & Partial & Quant & Yes & Yes \\
\hline Shawareb, 2011 & Jordan & $\mathrm{K}$ & new areas & $\begin{array}{l}\text { Variety of Software } \\
\text { (stand alone and } \\
\text { non-specific) }\end{array}$ & 76 & Limited & Quant & No & No \\
\hline Volpe et al., 2011 & US & $\mathrm{K}$ & literacy, at-risk & $\begin{array}{c}\text { Tutoring with } \\
\text { Adult on Computer } \\
\text { (non-specific) }\end{array}$ & 4 & Partial & Quant & Yes & No \\
\hline Wild, 2011 & UK & $\bar{K}$ & social interactions & $\begin{array}{c}\text { Rhyme \& Analogy } \\
\text { Programme } \\
\text { (stand-alone) }\end{array}$ & 87 & Limited & Qual & Yes & No \\
\hline Wood et al., 2010 & UK & $\mathrm{K}$ & Literacy & e-books & 8 & Partial & Mixed & No & No \\
\hline
\end{tabular}

